\title{
Investigation of the Relationship Between Sexual Myths and Parent Attitudes of Turkish Women
}

\author{
Gülşen Selam ${ }^{1}$ Habib Erensoy ${ }^{2}$, Melek Gözde Luş ${ }^{3}$
}

Selam, G., Erensoy, H., \& Luş MG.(2020). Investigation of the relationship between sexual myths and parent attitudes of turkish women. Nesne, 8(17), 180-188. DOI: 10.7816/nesne-08-17-02

\section{Keywords} Attitude, parental attitude, myth, sexual myth

\begin{abstract}
The aim of this research is to determine the relationship between sexual myths and parent attitudes in women between the ages of 20-35. Whose have overprotective, inconsistent, repressive and authoritarian parents can not ask questions freely in sex related matters. The false information they learn from peers or digital media will facilitate the formation of sexual myths and it is important to determine that relationship with the suggestions. The sample of this study consisted of 83 randomly selected women aged 20-35 years. Sociodemographic Data Form, Parent Attitude Scale and Sexual Myths Evaluation Form were applied in the study. We found that, according to the economic level, SMF scores differ significantly and SMF scores differ significantly according to educational level. It has been determined that the level of protective-willing parental attitudes also differs in terms of education level.When the authoritarian attitude subscale scores of women were analysed according to age, economic level and education level variable no significant difference was observed. A low level of positive correlation was found between sexual myth levels and protective-willing attitudes. As a result of the research, various suggestions were made.

\section{Türk Kadınlarının Cinsel Mitleri ve Ebeveyn Tutumları Arasındaki İlişkinin İncelenmesi}

Öz

$\mathrm{Bu}$ araştırmanın amacı, 20-35 yaş arası kadınlardaki cinsel mitler ve anne baba tutumları arasındaki ilişkinin belirlenmesini içermektedir. Aşırı korumacı, tutarsız, baskıcı ve otoriter bir ebeveyne sahip olanlar, cinsiyetle ilgili konularda serbestçe soru soramazlar. Akranlardan veya dijital medyadan öğrendikleri yanlış bilgiler, cinsel mitlerin oluşumunu kolaylaştıracak ve önerilerle ilişkinin belirlenmesi önemlidir.Bu çalışmanın örneklemini 20-35 yaşları arasında rastgele seçilen 83 kadından oluşmaktadır. Araştırmada Sosyodemografik Veri Formu, Veli Tutum Ölçeği ve Cinsel Mitler Değerlendirme Formu uygulanmıştır. Ekonomik seviyeye ve eğitim seviyesine göre ölçek puanlarında farklılıklar olduğu tespit edilmiştir. Koruyucu istekli ebeveyn tutumlarının düzeyinin eğitim düzeyine göre değiştiği tespit edilmiştir. Cinsel mit düzeyleri ile demokratik ve otoriter ebeveyn tutumları arasında anlamsız bir ilişki olduğu belirlenmiştir. Cinsel mit düzeyleri ile koruyucu istekçi ebeveyn tutumları arasında düşük düzeyde bir pozitif ilişki bulunmuştur. Araştırma sonucunda çeşitli önerilerde bulunulmuştur.
\end{abstract}

${ }^{1}$ Clinical Psychologist, Üsküdar University, Department of Psychology, ORCID 0000-0002-2797-9269

${ }^{2}$ Assistant Professor of Psychiatry, Üsküdar University, Department of Psychiatry, habiberensoy(at)yahoo.com, ORCID 0000-0002-4278-2739 ${ }^{3}$ Psychiatrist, Health Science Haydarpaşa Numune Training and Research Hospital, Child and Adolescent Psychiatry Department, ORCID 0000-0002-0430-9289 
Sexuality is a set of behaviors consisting of more than one component that has its own characteristics and complex structure. According to the World Health Organization, sexual health is sexuality-related physical, emotional, mental, and social well-being (WHO, 2006). Sexual myths (SM). are often described as beliefs that are shaped in the context of exaggerated, incorrect, or non-scientific values, and which are considered to be true of sexuality (Martyniuk et al., 2015; Torun et al., 2011). These myths are a major obstacle to communication in sexual life and can cause sexual dysfunction. Sexual false beliefs might have adverse effects on the sexual, and consequently, the general health of individuals (Nyanzi et al., 2005;Ejder et al., 2015). Cultural factors, social norms and religious beliefs affect the way we view sexuality. Traditions and religious beliefs are the most important factors that affect sexuality. It is stated that sexuality is approached from a distance in every region of the world and this stems from religious rules, social values, taboos and religious rules (Ahrold, Farmer, Trapnell, \& Meston, 2011; Hernandez, Mahoney, \& Pargament, 2014). In our society, it is common to think that sexuality is a shame or a sin, that it is forbidden to have sexual intercourse before marriage, and that a man should be more active in sexual action (Evcili and Golbasi, 2019). Incorrect or incomplete information causes anxiety, guilt and various fears. Sexuality and sexual education especially in western society in recent years has taken its place in academic programs and is left to the sexual education training center and / or the relevant health center, so to speak (Gureeraet al, 2019). In addition, the ease of access to sexual information, Internet, TV and social networks are widely used, but the information gained often there are incomplete, incorrect, or even self-contradictory information. However, most adolescents believe they are knowledgeable (.Garcia-Vega et al., 2012). This emphasizes the importance of family attitude and sexual education in the family.

In sexual education, learning begins from the family and continues throughout life. Parents are the primary source of socialization and and play an important role in ensuring that their children have healthy sexuality (Jankovic and Malatestinić, 2013). Wideman et al., in a meta-analysis showed that, overall, adolescents whose parents talk to them about sexuality generally exhibit safer sexual behaviors (Widman et al. 2015). In the Marston and King studies, beyond the lack of information, it also points to the importance of factors such as poor communication, myths and stamps related to condom use, and sex stereotypes that prevent safe sex behavior or spouse communication (Marston, King., 2006). Therefore, it is very important that families provide a healthy sexual education. In their study, Fadul et al. (2019) observed that more than three quarters of the women diagnosed with vaginismus and slightly more than half of the women in the control group were educated under an authoritarian style of upbringing.

Parental over-protective, inconsistent, repressive and authoritarian attitudes means that individuals cannot easily ask questions about sexual matters. Those who cannot receive sexual education from their families will try to satisfy their curiosity about sexuality from peer group or digital media and as a result, false, unsound scientific information will be learned. This false information will facilitate the formation of sexual myths. Therefore, it is important to determine the relationship between sexual myths and parental attitudes and to contribute to the literature with suggestions.

Ekmen et al. (2017) in their study with 100 primer infertile and 78 fertile women, found that the level of belief in sexual myths was statistically significant in 9 of 30 myths compared to the control group in infertile women was significantly higher. When they examined the factors affecting believing sexual myths, belief in some sexual myths was found to be statistically significantly high in uneducated women living in a large family in rural areas, Turkish society, is one of the societies with taboos on topics. Virginity, 
homosexuality, masturbation, extramarital sexual intercourse, sexual intercourse, pregnancy, breastfeeding and sexuality during menstrual periods and sexual issues are not explicitly discussed (Derya et al., 2017). But, this particular family attitudes and sexual taboos related studies in Turkey on etkisiyel very small.

The level of the relationship between sexual myths and parental attitudes in women between the ages of 20-35 is the question of our study. Our hypothesis is that there is a positive relationship between the level of sexual myth and the democratic parental attitude and negative relationship between the protective, willing and authoritarian parental attitudes in women between the ages of 20-35.

\section{Participants}

\section{Method}

The sample of this pilot study consisted of 83 women who are selected with the simple random method. They were enrolled if they had been living in Istanbul, age between 20-35 and have a sexual partner. Women older than 35 years, those with chronic medical illness and any psychiatric disorders were excluded. The study consent form was carefully read and completed by all patients.

\section{Measures}

Sociodemographic Data Form: In this form prepared by the responsible person, in order to learn the sociodemographic information of the participants.

Parent Attitude Scale (PAS): Parent Attitude Scale was developed by Kuzgun (1972). Eldeleklioğlu (1996) revised the scale and aimed to determine the parent's approach to their children. PAS is a scale that aims to measure parent's attitude (democratic, authoritarian, protective-willing). It is expected from the participants to examine the behaviors in the given statements and to indicate the level of the behaviors in which the parents are educating them. PAS consists of 40 items and has 3 subscales as democratic (17 items), protective-demanding (10 items), and authoritarian attitude (15 items). The scale's internal consistency reliabilities were 0.89 for democratic, 0.82 for protectivedemanding and 0.78 for authoritarian parenting styles (Kuzgun \& Eldeleklioğlu, 2005). PAS is a likert-type rating scale, filled by the individual participating in the study.. The answers given are calculated between 1 and 5 points. Democratic attitude consists of items $1,2,6,7,13,14,15,20,21,22,29,30,36,37,39$. The protective-willing attitude consists of articles 4, 9, $10,11,17,18,19,24,25,26,27,28,32,33$ and 34, while the items of the Authoritarian attitude are 3, 5, 8, 12, 16. Are 23, 31, 35, 38 and 40 .

Sexual Myths Evaluation Form (SMF): The SMF consists of 30 sexual myths developed by Zilbergeld (1999) that have been used in the investigation of common sexual myths in our country. For each suggestion in the sexual myth assessment form, the respondents were asked to mark either 'agree', 'disagree 'or 'no idea' (Kora, Kayır; 1996). Sexual Myths Evaluation Form consists of 15 items. Sexual Myths Evaluation Form, which contains different myths, is answered as "Yes" or "No".

\section{Procedure}

This study protocol was approved by the Institutional Review Board of the non-invasive ethics committee of Üsküdar University, approval number B.08.6.YÖK.2.ÜS.0.05.0.06/2017/256 and dated $17 / 10 / 2017$. Informed consent of each participant was obtained. 


\section{Analysis of Data}

Kruskal Wallis Test was used for continuous variables. Since the distributions were not normal, nonparametric tests were applied to the variables. The relationship between sexual myth and parental attitudes variables was evaluated with Spearman Rank Differences Correlation Coefficient, $\mathrm{p}$ value was taken as $<0.05$. The outcome variables of the study are sexual myths and parental attitudes.

\section{Results}

Table 1 shows the distribution of the participants according to their sociodemographic characteristics. While 24 of the women who participated in the study were between 20-25 years old, 37 were between 26-30 years old and 22 were between 31-35 years old. 39 participants have good economic income, 41 participants have moderate economic income and 3 participants have low economic income. When education level is examined, it is determined that 1 of the women is illiterate, 4 of them are primary school graduates, 1 of them is secondary school graduate, 11 of them are high school graduates and 66 of them are university graduates (see Table 1).

Table 1

Distribution of Demographic Variables of Participants

\begin{tabular}{llll}
\hline Variable & & $\boldsymbol{N}$ & $\boldsymbol{\%}$ \\
\hline Age & $20-25$ years & 24 & 28,9 \\
& $26-30$ years & 37 & 44,6 \\
Ekonomic Status & $31-35$ years & 22 & 26,5 \\
& High & 39 & 47,0 \\
& Middle & 41 & 49,4 \\
Education Level & Low & 3 & 3,6 \\
& Illaterate & 1 & 1,2 \\
& Primary school & 4 & 4,8 \\
& Secondary School & 1 & 1,2 \\
& High School & 11 & 13,3 \\
& University & 66 & 79,5 \\
\hline
\end{tabular}

Comparison of the scores obtained from the SMF according to demographic variables was analyzed by the Kruskal Wallis test and is shown in Table 2. When the results were examined, it was determined that SMF scores did not differ according to age $[\chi 2(2)=, 055 ; p=973 ; p>05]$. According to the economic level, SMF scores differ significantly $\left[\chi^{2}(2)=7,026 ; p=, 030 ; p<.05\right]$. SMF scores of women with low economic income were found to be significantly higher than those with high economic income. When the education level is examined, it was determined that SMF scores differ significantly $[\chi 2(4)=24,920 ; p=000 ; p<.05]$. It was determined that the sexual myth levels of women who primary school graduates were significantly higher than those of university graduates. Although the scores obtained from the scale differ according to the other education levels, the difference was not significant (see Table 2). 
Table 2

Comparison of the scores obtained from the SMF according to demographic variables

\begin{tabular}{llrrrrr}
\hline & & $\boldsymbol{N}$ & Mean & \multicolumn{1}{c}{$\boldsymbol{S S}$} & $\mathbf{x}^{\mathbf{2}}$ & $\mathbf{p}$ \\
\hline Age & 20-25 years & 24 & 4,83 & 3,91 & & \\
& 26-30 years & 37 & 4,90 & 3,92 &, 055 & .97 \\
Ekonomic Status & 31-35 years & 22 & 4,63 & 3,71 & & \\
& High & 39 & 3,90 & 3,42 & & \\
Education Level & Middle & 41 & 5,27 & 3,82 & 7,026 & $\mathbf{. 0 3}$ \\
& Low & 3 & 10,33 & 4,04 & & \\
& Illaterate & 1 & 14,00 &. & & \\
& Primary school & 4 & 8,25 & 1,26 & & \\
& Secondary School & 1 & 7,00 &. & 24,920 & $\mathbf{. 0 0}$ \\
& High School & 11 & 9,27 & 3,23 & & \\
\hline
\end{tabular}

Table 3

Comparison of PAS subscale scores according to demographic variables

\begin{tabular}{|c|c|c|c|c|c|c|c|}
\hline & & & $N$ & Mean & SS & $\mathbf{x}^{2}$ & p \\
\hline \multirow{11}{*}{ Democratic Attitude } & \multirow[t]{3}{*}{ Age } & $20-25$ years & 24 & 59,58 & 8,93 & 5,278 & \\
\hline & & $26-30$ years & 37 & 55,84 & 9,59 & & .07 \\
\hline & & $31-35$ years & 22 & 50,18 & 15,59 & & \\
\hline & \multirow[t]{3}{*}{ Ekonomic Status } & High & 39 & 55,95 & 12,64 & ,957 & \multirow{3}{*}{.62} \\
\hline & & Middle & 41 & 54,66 & 10,99 & & \\
\hline & & Low & 3 & 59,00 & 12,17 & & \\
\hline & \multirow[t]{5}{*}{ Education Level } & İllaterate & 1 & 51,00 & & 2,958 & \multirow{5}{*}{.56} \\
\hline & & Primary school & 4 & 63,25 & 6,70 & & \\
\hline & & $\begin{array}{l}\text { Secondary } \\
\text { School }\end{array}$ & 1 & 56,00 & . & & \\
\hline & & High School & 11 & 52,64 & 12,86 & & \\
\hline & & University & 66 & 55,47 & 11,86 & & \\
\hline \multirow{11}{*}{ Protective-willing Attitude } & \multirow[t]{3}{*}{ Age } & $20-25$ years & 24 & 35,33 & 11,03 & & \\
\hline & & 26-30 years & 37 & 38,49 & 10,81 & 2,839 & .24 \\
\hline & & 31-35 years & 22 & 38,09 & 9,01 & & \\
\hline & \multirow[t]{3}{*}{ Ekonomic Status } & High & 39 & 35,31 & 9,06 & & \\
\hline & & Middle & 41 & 39,83 & 10,71 & 4,969 & .08 \\
\hline & & Low & 3 & 33,33 & 18,77 & & \\
\hline & \multirow[t]{5}{*}{ Education Level } & İllaterate & 1 & 55,00 & & & \\
\hline & & Primary school & 4 & 30,75 & 6,55 & & \\
\hline & & $\begin{array}{l}\text { Secondary } \\
\text { School }\end{array}$ & 1 & 47,00 & . & 12,127 & .02 \\
\hline & & High School & 11 & 44,18 & 8,86 & & \\
\hline & & University & 66 & 36,35 & 10,23 & & \\
\hline \multirow{11}{*}{ Authoritarian Attitude } & \multirow[t]{3}{*}{ Age } & $20-25$ years & 24 & 21,96 & 6,47 & 2,878 & \multirow{3}{*}{.24} \\
\hline & & $26-30$ years & 37 & 23,78 & 7,91 & & \\
\hline & & $31-35$ years & 22 & 26,68 & 9,47 & & \\
\hline & \multirow[t]{3}{*}{ Ekonomic Status } & High & 39 & 23,79 & 7,63 & 1,026 & \multirow{3}{*}{.60} \\
\hline & & Middle & 41 & 24,54 & 8,57 & & \\
\hline & & Low & 3 & 20,00 & 8,72 & & \\
\hline & \multirow[t]{5}{*}{ Education Level } & İllaterate & 1 & 30,00 & 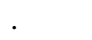 & 5,853 & \multirow{5}{*}{.21} \\
\hline & & Primary school & 4 & 23,75 & 10,90 & & \\
\hline & & $\begin{array}{l}\text { Secondary } \\
\text { School }\end{array}$ & 1 & 34,00 & . & & \\
\hline & & High School & 11 & 28,18 & 8,49 & & \\
\hline & & University & 66 & 23,11 & 7,75 & & \\
\hline
\end{tabular}


Table 3 shows the comparison of PAS subscale scores according to demographic variables. Comparison was made with Kruskal Wallis Test. The scores of democratic attitude subscale of women according to age variable $\left[\chi^{2}(2)=5,278 ; p=, 071 ; p>05\right]$ according to the economic level variable $[\chi 2(2)$ $=, 957 ; p=620 ; p>, 05]$ and educational level variable $[\chi 2(4)=2,958 ; p=565 ; p>05]$ were investigated. Accordingly, it was determined that the scores did not show significant differences. When the protectivewilling attitude subscale scores of women were examined according to age variable $\left[\chi^{2}(2)=2,839 ; p=, 242\right.$; $p>, 05]$ and economic level variable $\left[\chi^{2}(2)=4,969 ; p=, 083 ; p>, 05\right]$ it was found that the scores obtained did not show significant difference. It was determined that the protective-willing attitude subscale scores differed significantly. According to the educational level variable $\left[\chi^{2}(4)=12,127 ; p=0.16 ; p<0.05\right]$. The protective-willing attitude subscale scores of high school graduates were found to be significantly higher than those of primary and university graduates. When the authoritarian attitude subscale scores of women were analyzed according to age variable $\left[\chi^{2}(2)=2.878 ; \mathrm{p}=0.237 ; \mathrm{p}>0.05\right]$ economic level variable $\left[\chi^{2}(2)=1,026 ; p=, 599 ; p>, 05\right]$ and education level variable $\left[\chi^{2}(4)=5,853 ; p=, 210 ; p>, 05\right]$ no significant difference was observed (see Table 3 ).

Table 4 shows the comparison of the relationship between SMF and the PAS scores. As a result of the analyzes, a meaningless relationship between sexual myth levels and democratic and authoritarian attitude scores was determined $(\mathrm{p}>.05)$. On the other hand, a positive low-level significant relationship was found between sexual myth levels and protective-willing attitude scores ( $\mathrm{p}<.05)$ (see Table 4).

Table 4

Comparison of the Relationship Between SMF and PAS Scores

\begin{tabular}{lll}
\hline SMF & Pearson Correlation & Sig. (2-Tailed) \\
\hline Demokratic Attitude & .08 & .50 \\
Protective-willing Attitude & $.24^{*}$ & .03 \\
Authoritarian Attitude & .12 & .30 \\
\hline
\end{tabular}

$* \mathrm{p}<.05$

\section{Discussion}

In the current study we examined the relationship between sexual myths and parental attitudes in women aged 20-35 years. According to the data obtained in our study, it is seen that sexual myth levels of women do not show significant differences according to age. In a study conducted by Aygin et al. (2017), it was found that the level of belief in sexual myths differed according to the age variable. Many research shows that especially young people have sexual myths and lack of knowledge about sexuality (Lefkowitz et al., 2014; Morris et al., 2015). In our study, sexual myth levels of women with low economic income were significantly higher than those with high economic income. The basis of sexual myths is the lack of sufficient information or misinformation (Shiferaw et al,, 2014; Tesso et al., 2012). Sexual myths cause couples to have high expectations of each other or themselves. The most important element of sexual myths is the coexistence of sexuality and value judgments in almost all societies. This has limited the possibility of discussing and investigating issues of sexuality clearly. Psychosocial factors of age, education, income, and ethnicity can also be possible causes of female sexual dysfunction (Clayton et al., 2019). In our study, it was found that sexual myth levels of women differed significantly according to education level. It was 
determined that gender myth levels of primary school graduate women were significantly higher than those of university graduates. In the light of the results obtained in our study, it is thought that the fact that women with primary school graduation have incomplete or incorrect information about sexuality may lead to an increase in sexual myth.

One of the important factors affecting the attitudes of parents is age and birth order. Expectations from the first children are higher and these children are given more responsibility by pretending to be grown up while younger children are more tolerated (Hotz and Pantano, 2015). It is thought that the birth order of the women constituting the sample of our study can be an important factor and conducting the examinations accordingly may give more definite results.

Parental attitude is very important for children and adolescents to establish healthy relationships with their environment, also affect the child especially during adolescence period (Dyavanoor and Jyoti, 2017; Moed et al., 2017). In our study, there was no significant difference in democratic parental attitude scores according to the economic status of the participants, and there was no significant difference in democratic parental attitude scores according to the educational status of the participants that did not agree with the literature on family attitudes. Kulakci-Altintas and Ayaz-Alkaya (2019), found in their study that factors such as grade level, age, sex, education level of the parents, family structure, income level, number of siblings, birth order, state of being exposed to domestic violence, and tendency for violence affected perceived parental attitude. In our study, there was no significant difference also in protective-willing parent attitude levels according to age and economic status and there was no significant difference also in authoritarian parental attitudes according to age, economic and educational status. It is seen that the distribution of the economic situation of women ages between 20-35 is mostly high and moderate. It can be concluded that the living standards of the women participating in the survey are at a certain level. Accordingly, it can be stated that the mentioned situations did not make a difference in the levels of perceived authoritarian parental attitude and that the authoritarian attitude would be perceived at a similar level.

While it is expected that there will be a relationship between parental attitudes and sexual myth levels, no significant relationship was found between sexual myths and democratic and authoritarian parental attitudes and a positive low-level relationship was found between protective-willing parent attitude in our study. These results suggest that spouses and circle of friends may have an impact on sexual myths. While democratic parental attitude leads to positive results in emotional and social development, it is known that authoritarian and protective parental attitudes have negative effects on development (Şanlı and Öztürk, 2015). In protective-willing parent attitude, parents restrict their children's behavior and show conditional love. Conservative and patriarchal family structure makes communication difficult between family members relating to sexuality, therefore especially young people tend to see their friends as a source of information about sexuality (Evcili F, Golbasi Z., 2019; Al-Quaiz et al., 2013). Children of protective-willing parents will not be able to obtain information about sexuality from the family, and will receive this information in digital environments or from friends. This will lead to an increase in the level of sexual myth. The number of studies in this area is limited in Turkey.

This study is a cross-sectional study and conducted with a narrow group. Besides, the scales used in the study are self-report questionnaires which may compromise the validity of diagnosis, studies including individual interviews should be planned. It is thought that prospective longitudinal studies with larger groups are needed and increasing the Turkish sample and expanding the age of group would be beneficial. 


\section{References}

Ahrold, T. K., Farmer, M., Trapnell P. D., \& Meston, C. M. (2011). The relationship among sexual attitudes, sexual fantasy, and religiosity. Archives of Sexual Behavior, 40, 619-630.

Al-Quaiz, J. M, Kazi, A., \& Al-Muneef, M. (2013) Determinants of sexual health knowledge in adolescent girls in schools of Riyadh-Saudi Arabia: a cross-sectional study. BMC Womens Health. 13(1), 1-8.

Aygin, D., Açıl, H., Yaman, Ö., \& Çelik Yılmaz, A. (2017). Üniversitede okuyan kadın öğrencilerin cinsel mitler ile ilgili görüşleri. Androloji Bülten, 19(2), 44-49.

Clayton, A. H., \& Valladares Juarez, E. M. (2019). Female Sexual Dysfunction. Med Clin North Am. Jul, 103(4), 681-698.

Derya, A. Y., Taşhan S. T., Uçar, T., Karaaslan, T., \& Tunç, Ö. A. (2017). Toplumsal cinsiyet rollerine ilişsin tutumların cinsel tabulara etkisi. Gümüşhane Üniversitesi Sağllk Bilimleri Dergisi Archive, $6(1), 1-8$.

Dyavanoor, B. D., \& Jyoti, D. M. (2017). Parents' attitudes and beliefs: Their impact on children's development. International Journal of Physical Education and Sports Sciences, 11(18), 241-243.

Ejder Apay, S., Özorhan, E. Y., Arslan, S., Özkan, H., Koc, E., \& Özbey, I. (2015). The sexual beliefs of Turkish men: comparing the beliefs of men with and without erectile dysfunction. J Sex Marital Ther, 41(6), 661-671.

Ekmen, B. U., Özkan, M., Gül, T. (2017). Infertilite tedavisi gören kadınlarda cinsel mitlere inanma düzeyi. Klinik Psikiyatri, 20, 209-217 DOI: 10.5505/kpd.2017.33043

Eldeleklioğlu, J. (1996). Karar stratejileri ile anne-baba tutumları arasındaki ilişki (Unpublished dissertation). University of Gazi, Ankara.

Evcili, F., \& Golbasi, Z. (2019) The effect of peer education model on sexual myths of Turkish university students: An interventional study. Perspect Psychiatr Care., 55(2), 239-248.

Fadul, R., Garcia, R., Zapata-Boluda, R., Aranda-Pastor C, Brotto L, Parron-Carreño T, \& AlarconRodriguez R. (2019). Psychosocial correlates of vaginismus diagnosis: A case-control study. J Sex Marital Ther. 45(1), 73-83.

García-Vega, E., Menéndez, E. Fernández, P., Cuesta, M. (2012). Sexualidad, anticoncepción y conducta sexual de riesgo en adolescentes. int J Psychol Res. 5, 79-87.

Guerra, C., Del Río, F. J., Cabello, F., \& Morales, I. M. (2019) Creation and validation of a scale of sexuality for adolescents: Scale of Myths about Sexuality. Rev Int Androl., 17(4), 123-129. Doi: 10.1016/j.androl.2018.06.001.

Hernandez, K. M., Mahoney, A., \& Pargament, K. I. (2014). Sexuality and religion. In D. L. Tolman \& L. M. Diamond (Ed.), APA handbook of sexuality and psychology: Vol. 2. Contextual approaches (pp. 425-447). Washington, DC: American Psychological Association.

Hotz, V. J., \& Pantano, J. (2015). Strategic parenting, birth order, and school performance. J PopulEcon, 28(4), 911936.

Jankovic, S., \& Malatestinić, G. (2013) Parents' attitudes on sexual education - What and when? Collegium antropologicum, 37(1), 17-22.

Kora, K., \& Kayır, A. (1996) Cinsel roller ve cinsel mitler. Düşünen Adam Psikiyatri ve Nörolojik Bilimler Dergisi, 9, 55-58.

Kulakci-Altintas, H., \& Ayaz-Alkaya, S. (2019) Parental attitudes perceived by adolescents, and their tendency for violence and affecting factors. J Interpers Violence, 34(1), 200-216.

Kuzgun, Y. (1972) Ana-baba tutumlarının kendini gerçekleştirme düzeyine etkisi (Unpublished doctoral thesis). Hacettepe Üniversitesi, Sosyal Bilimler Enstitüsü. 
Kuzgun, Y., \& Eldeleklioglu, J. (2005). Ana baba tutumları ölçeği. (Parental attitudes scale. Measurements and programs used in psychological counseling and guidance), (pp. 53-70).] In Y. Kuzgun and F. Bacanli (Eds.). Ankara: Nobel Publishing.

Lefkowitz, E. S., Shearer, C. L., Gillen, M. M., \& Espinosa-Hernandez, G. (2014) How gendered attitudes relate to women's and men's sexual behaviors and beliefs. Sex Cult. 18(4), 833-846. Doi:10.1007/s12119-014-9225-6

Marston, C., \& King, E. (2006) Factors that shape young people's sexual behaviour: a systematic review. Lancet, 368(9547), 1581-6.

Martyniuk, U., Dekker, A., Sehner, S., Richter-Appelt, H., \& Briken, P. (2015). Religiosity, sexual myths, sex taboos, and pornography use: a crossnational comparison of Polish and German university students. Cyberpsychology: Journal of Psychosocial Research on Cyberspace, 9(2), 1-16.

Moed, H. A., Gershoff, E. T., \& Bringewatt, E. H. (2017). Violence exposure as a mediator between parenting and adolescent mental. Child Psychiatry and Human Development, 48, 235-247.

Morris, J. L., \& Rushwan, H. (2015) Adolescent sexual and reproductive health: the global challenges. Int J of Gynecology Obstet. 131(1), 40-42.

Nyanzi, S., Nyanzi, B., Kalina, B. (2005). Contemporary myths, sexuality misconceptions, information sources, and risk perceptions of bodabodamen in southwest Uganda. Sex Roles, 52(1), 111-119.

Shiferaw, K., Getahun, F., \& Asres, G. (2014) Assessment of adolescent's communication on sexual and reproductive health matters with parents and associated factors among secondary and preparatory school's students in Debremarkos town. North West Ethiopia. Reprod Health, 11(1), 2.

Şanlı, D., \& Öztürk, C. (2015). Parenting attitudes of parents and culture effect onattitudes. Dokuz Eylül Üniversitesi Hemşirelik Fakültesi Elektronik Dergisi, 8(4), 240-246.

Tesso, D. W., Fantahun, M. A., \& Enquselassie, F. (2012) Parent-young people communication about sexual and reproductive health in E/Wollega zone, West Ethiopia: implications for interventions. Reprod Health. 16(9), 13.

Torun, F., Torun, S. D., \& Ozaydın, N. (2011). Factors affecting beliefs in myths and beliefs in sexual myths in men. Thinking Man Journal of Psychiatry and Neurological Sciences. 24(1), 24-31.

Widman, L., Choukas-Bradley, S., Noar, S. M., Nesi, J., \& Garrett, K. (2015). Parent-adolescent sexual communication and adolescent safer sexual behavior: A meta-analysis. JAMA Pediatrics, 170, 5261.

World Health Organization (2006). Defining sexual health. http://www. who.int/reproductivehealth/topics/sexual_health/sh_definitions/en/. Accessed March 12, 2016

Zilbergeld, B. (1999). The new male sexuality. Bantam. 